\title{
Mechanistic study of ruthenium (III) catalysed oxidation of L-lysine by diperiodatoargentate (III) in aqueous alkaline medium
}

\author{
R R HOSAMANI and S T NANDIBEWOOR* \\ PG Department of Studies in Chemistry, Karnatak University, Dharwad 580003 \\ e-mail: stnandibewoor@yahoo.com
}

MS received 15 April 2008; revised 2 July 2008

\begin{abstract}
The kinetics of Ru(III) catalysed oxidation of L-lysine by diperiodatoargentate (III) (DPA) in alkaline medium at $298 \mathrm{~K}$ and a constant ionic strength of $0.50 \mathrm{~mol} \mathrm{dm}{ }^{-3}$ was studied spectrophotometrically. The oxidation products are aldehyde (5-aminopentanal) and Ag (I). The stoichiometry is i.e. $[\mathrm{L}-$ lysine] $:[\mathrm{DPA}]=1: 1$. The reaction is of first order in $[\mathrm{Ru}(\mathrm{III})]$ and $[\mathrm{DPA}]$ and is less than unit order in both [L-lys] and [alkali]. Addition of periodate had a retarding effect on the reaction. The oxidation reaction in alkaline medium has been shown to proceed via a $\mathrm{Ru}(\mathrm{III})$-L-lysine complex, which further reacts with one molecule of monoperiodatoargentate(III) (MPA) in a rate determining step followed by other fast steps to give the products. The main products were identified by spot test, IR, GC-MS studies. The activation parameters with respect to slow step of the mechanism are computed and discussed and thermodynamic quantities are also determined. The active species of catalyst and oxidant have been identified.
\end{abstract}

Keywords. Kinetics of oxidation; L-lysine- Ru(III) catalysis; diperiodatoargentate(III).

\section{Introduction}

The study of amino acids becomes important because of their biological significance and selectivity towards the oxidant. ${ }^{1.2}$ L-lysine is an essential amino acid and one gets it from food. Some evidence suggests that supplemental L-lysine ${ }^{3}$ may be able to help to prevent herpes infections (cold sores and genital herpes).

Diperiodatoargentate(III) (DPA) is a powerful oxidizing agent in alkaline medium with the reduction potential ${ }^{4} 1.74 \mathrm{~V}$. It is widely used as a volumetric reagent for the determination of various organic and inorganic species. ${ }^{5}$ Jaya Prakash Rao et $a l^{6}$ have used DPA as an oxidizing agent for the kinetics of oxidation of various organic substrates. They normally found that order with respect to both oxidant and substrate was unity and $\left[\mathrm{OH}^{-}\right]$was found to enhance the rate of reaction. It was also observed that they did not arrive the possible active species of DPA in alkali and on the other hand they proposed mechanisms by generalizing the DPA as [Ag $(\mathrm{HL}) \mathrm{L}]^{(x+1)-}$. However, Anil Kumar et $a l^{7}$ put an effort

\footnotetext{
*For correspondence
}

to give an evidence for the reactive form of DPA in the large scale of alkaline $\mathrm{pH}$. In the present investigation, we have obtained the evidence for the reactive species for DPA in alkaline medium.

Ruthenium(III) acts as an efficient catalyst in many redox reactions involving several complexes, different oxidation states of ruthenium, etc. The uncatalysed oxidation of L-lysine by DPA has been studied ${ }^{8}$ We have observed that ruthenium(III) catalyses the oxidation of L-lysine by DPA in alkaline medium in micro amounts. In order to understand the active species of oxidant and catalyst, and to propose the appropriate mechanism, the title reaction is investigated in detail.

\section{Experimental}

All chemicals used were of reagent grade and double distilled water was used throughout the work. A solution of L-lysine (s.d.-Fine) was prepared by dissolving an appropriate amount of recrystallised sample in double distilled water. Its purity was checked by IR and NMR Spectra. A stock solution of Ru(III) was prepared by dissolving $\mathrm{RuCl}_{3}$ (s.d.-Fine chemicals) in $0.20 \mathrm{~mol} \mathrm{dm}^{-3} \mathrm{HCl}$. The concentration was determined $^{9}$ by EDTA titration. $\mathrm{KNO}_{3}$ and 
$\mathrm{KOH}(\mathrm{BDH})$ were used to maintain the ionic strength and alkalinity of the reaction, respectively. An aqueous solution of $\mathrm{AgNO}_{3}$ was used to study the product effect, $\mathrm{Ag}(\mathrm{I})$. A stock standard solution of $\mathrm{IO}_{4}^{-}$ was prepared by dissolving a known weight of $\mathrm{KIO}_{4}$ (Riedel-de Haen) in hot water and used after keeping for $24 \mathrm{~h}$. Its concentration was ascertained iodometrically ${ }^{10}$ at neutral $\mathrm{pH}$ maintained using phosphate buffer. The $\mathrm{pH}$ of the medium in the solution was measured by ELICO (LI613) $\mathrm{pH}$ meter.

DPA was prepared by oxidizing $\mathrm{Ag}(\mathrm{I})$ in presence of $\mathrm{KIO}_{4}$ as described elsewhere ${ }^{11}$ and analysed by standard method. ${ }^{12}$

\subsection{Kinetic studies}

Since the initial reaction was too fast to be monitored by usual methods, kinetic measurements were performed on a Hitachi 150-20 Spectrophotometer connected to a rapid kinetic accessory (HI-TECH SFA-12).

The kinetics was followed under pseudo-first order condition where [L-lys] $>$ [DPA] at $25 \pm 0 \cdot 1^{\circ} \mathrm{C}$, unless specified. The progress of reaction was followed spectrophotometrically at $360 \mathrm{~nm}$ by monitoring decrease in absorbance due to DPA (' $\varepsilon_{\mathrm{DPA}}$ ' $=$ $13900 \pm 100 \mathrm{dm}^{3} \mathrm{~mol}^{-1} \mathrm{~cm}^{-1}$ ).

The pseudo-first order rate constants, ' $k_{C}$ ', were determined from the log (absorbance) $v s$ time plots. The plots were linear up to $85 \%$ completion of reaction under the range of $\left[\mathrm{OH}^{-}\right]$used. The reaction orders were determined from the slopes of $\log k c$ versus $\log$ (concentration) plots, by varying the concentration of reductant, catalyst and alkali, while keeping others constant.

\section{Results}

\subsection{Stoichiometry and product analysis}

Different sets of reaction mixtures containing excess DPA over L-lysine in presence of constant amounts of $\mathrm{OH}^{-}, \mathrm{Ru}(\mathrm{III})$ and $\mathrm{KNO}_{3}$, were kept for $3 \mathrm{~h}$ in a closed vessel under nitrogen atmosphere. The remaining concentration of DPA was estimated by spectrophotometrically at $360 \mathrm{~nm}$. The results indicated that one mole of DPA consumed one mole of L-lysine (1:1 stoichiometry) as given in (1).

$$
\begin{array}{cc}
\mathrm{R}-\mathrm{CH}-\mathrm{COO}^{-} & +\left[\mathrm{Ag}\left(\mathrm{H}_{2} \mathrm{IO}_{6}\right)\left(\mathrm{H}_{2} \mathrm{O}\right)_{2}\right) \stackrel{\mathrm{Ru}(\mathrm{III})}{\longrightarrow} \\
\mathrm{NH}_{2} & \\
& \begin{array}{c}
\mathrm{R}-\mathrm{CHO}+\mathrm{Ag}(\mathrm{I})+\mathrm{NH}_{3}+\mathrm{CO}_{2} \\
\\
\end{array} \\
& +\mathrm{H}_{2} \mathrm{O}+\mathrm{H}^{+}+\mathrm{H}_{2} \mathrm{IO}_{6}^{3-}
\end{array}
$$

where $\mathrm{R}=-\mathrm{CH}_{2}-\mathrm{CH}_{2}-\mathrm{CH}_{2}-\mathrm{CH}_{2}-\mathrm{NH}_{2}$.

The main oxidation products were identified as corresponding aldehyde (5-aminopentanal) by spot test, ammonia by Nessler's reagent. The product aldehyde was quantitatively estimated to about $70 \%$, which is evidenced by its 2,4-DNP derivative. The nature of 5-aminopentanal was confirmed by its IR spectrum which showed a $\mathrm{C}=\mathrm{O}$ stretching at $1631 \mathrm{~cm}^{-1}$ indicating the presence of aldehydic $\mathrm{C}=\mathrm{O}$, the band at $3424 \mathrm{~cm}^{-1}$ indicating the presence of $\mathrm{NH}_{2}$ group. It was also confirmed by its melting point $118^{\circ} \mathrm{C}$ (lit. m.p. $118-120^{\circ} \mathrm{C}$ ). Further, 5aminopentanal was subjected to GC-mass spectral analysis. The mass spectrum showed a molecular ion peak at $101 \mathrm{amu}$ confirming 5-aminopentanal, all other peaks observed in GC-MS can be interpreted in accordance with observed structure of the product.

\subsection{Reaction orders}

The total rate constant $\left(k_{T}\right)$ is equal to the sum of the rate constants of the catalysed $\left(k_{C}\right)$ and uncatalysed $\left(k_{U}\right)$ reactions, so $k_{C}=k_{T}-k_{U}$. Hence the reaction orders have been determined from the slopes of $\log k_{C}$ vs $\log$ (concentration) plots by varying the concentrations of L-lysine, $\mathrm{IO}_{4}^{-}, \mathrm{OH}^{-}$and $\mathrm{Ru}(\mathrm{III})$, in turn, while keeping others constant. The DPA concentration was varied in the range of $1.0 \times 10^{-5}$ to $1.0 \times 10^{-4} \mathrm{~mol} \mathrm{dm}^{-3}$ and the linearity of the plots of $\log$ (absorbance) vs time up to $85 \%$ completion of the reaction indicates a reaction order of unity in [DPA]. The deviation of linearity beyond $85 \%$ completion of the reaction might be due to the possibility of other reactions such as slow oxidation of product formed during reaction or oxidation of alkali by oxidant, etc. This is also confirmed by varying of [DPA], which did not result in any change in the pseudo-first order rate constants, $k_{C}$ (table 1). The L-lysine concentration was varied in the range $3.0 \times 10^{-4}$ to $3.0 \times 10^{-3} \mathrm{~mol} \mathrm{dm}^{-3}$ at $25^{\circ} \mathrm{C}$ while keeping other reactant concentrations and conditions constant. The $k_{C}$ values increased with the increase in concentration of L-lysine indicating an apparent less than unit order dependence on [L-lys] $(0.52)$. The effect of alkali on the reaction has been studied 
Table 1. Effect of [DPA], [L-lys], $\left[\mathrm{OH}_{-}^{-}\right]\left[\mathrm{IO}_{4}^{-}\right]$on the ruthenium(III) catalysed oxidation of L-lysine by DPA in alkaline medium at $25^{\circ} \mathrm{C}, I=0 \cdot 50 \mathrm{~mol} \mathrm{dm}^{-3}$.

\begin{tabular}{|c|c|c|c|c|c|c|c|c|}
\hline \multirow{2}{*}{$\begin{array}{l}10^{5}[\mathrm{DPA}] \\
\left(\mathrm{mol} \mathrm{dm}^{-3}\right)\end{array}$} & \multirow{2}{*}{$\begin{array}{l}10^{4}[\mathrm{~L}-\mathrm{lys}] \\
\left(\mathrm{mol} \mathrm{dm}{ }^{-3}\right)\end{array}$} & \multirow{2}{*}{$\frac{\left[\mathrm{OH}^{-}\right]}{\left(\mathrm{mol} \mathrm{dm}^{-3}\right)}$} & \multirow{2}{*}{$\begin{array}{c}10^{4}\left[\mathrm{IO}_{4}^{-}\right] \\
\left(\mathrm{mol} \mathrm{dm}^{-3}\right)\end{array}$} & \multirow{2}{*}{$\begin{array}{c}10^{6}[\mathrm{Ru}(\mathrm{III})] \\
\left(\mathrm{mol} \mathrm{dm}^{-3}\right)\end{array}$} & \multirow[b]{2}{*}{$10^{2} k_{T}\left(\mathrm{~s}^{-1}\right)$} & \multirow[b]{2}{*}{$10^{3} k_{U}\left(\mathrm{~s}^{-1}\right)$} & \multicolumn{2}{|c|}{$10^{2} k_{C}\left(\mathrm{~s}^{-1}\right)$} \\
\hline & & & & & & & Found & Calculated \\
\hline 1.0 & $5 \cdot 0$ & $0 \cdot 3$ & $1 \cdot 0$ & $3 \cdot 0$ & $2 \cdot 14$ & $2 \cdot 66$ & 1.87 & 1.97 \\
\hline $3 \cdot 0$ & $5 \cdot 0$ & $0 \cdot 3$ & 1.0 & $3 \cdot 0$ & $2 \cdot 13$ & $2 \cdot 65$ & 1.86 & 1.97 \\
\hline $5 \cdot 0$ & $5 \cdot 0$ & $0 \cdot 3$ & $1 \cdot 0$ & $3 \cdot 0$ & $2 \cdot 14$ & $2 \cdot 66$ & 1.87 & 1.97 \\
\hline $8 \cdot 0$ & $5 \cdot 0$ & $0 \cdot 3$ & $1 \cdot 0$ & $3 \cdot 0$ & $2 \cdot 15$ & $2 \cdot 65$ & 1.88 & 1.97 \\
\hline $10 \cdot 0$ & $5 \cdot 0$ & $0 \cdot 3$ & $1 \cdot 0$ & $3 \cdot 0$ & $2 \cdot 16$ & $2 \cdot 66$ & 1.89 & 1.97 \\
\hline $5 \cdot 0$ & $3 \cdot 0$ & $0 \cdot 3$ & 1.0 & $3 \cdot 0$ & 1.52 & $2 \cdot 35$ & $1 \cdot 28$ & $1 \cdot 35$ \\
\hline $5 \cdot 0$ & $5 \cdot 0$ & $0 \cdot 3$ & $1 \cdot 0$ & $3 \cdot 0$ & $2 \cdot 14$ & $2 \cdot 66$ & 1.88 & 1.97 \\
\hline $5 \cdot 0$ & $10 \cdot 0$ & $0 \cdot 3$ & $1 \cdot 0$ & $3 \cdot 0$ & $3 \cdot 23$ & $3 \cdot 19$ & 2.91 & 2.98 \\
\hline $5 \cdot 0$ & $15 \cdot 0$ & 0.3 & 1.0 & $3 \cdot 0$ & 3.77 & $3 \cdot 55$ & $3 \cdot 44$ & 3.59 \\
\hline $5 \cdot 0$ & $20 \cdot 0$ & $0 \cdot 3$ & $1 \cdot 0$ & $3 \cdot 0$ & $4 \cdot 20$ & 3.90 & $3 \cdot 81$ & $4 \cdot 00$ \\
\hline $5 \cdot 0$ & $30 \cdot 0$ & $0 \cdot 3$ & $1 \cdot 0$ & $3 \cdot 0$ & $4 \cdot 76$ & $4 \cdot 55$ & $4 \cdot 31$ & $4 \cdot 52$ \\
\hline $5 \cdot 0$ & $5 \cdot 0$ & 0.05 & $1 \cdot 0$ & $3 \cdot 0$ & 0.70 & $1 \cdot 04$ & 0.60 & 0.61 \\
\hline $5 \cdot 0$ & $5 \cdot 0$ & 0.08 & 1.0 & $3 \cdot 0$ & 1.05 & 1.40 & 0.91 & 0.89 \\
\hline $5 \cdot 0$ & $5 \cdot 0$ & $0 \cdot 1$ & $1 \cdot 0$ & $3 \cdot 0$ & $1 \cdot 20$ & 1.59 & 1.04 & 1.04 \\
\hline $5 \cdot 0$ & $5 \cdot 0$ & $0 \cdot 3$ & $1 \cdot 0$ & $3 \cdot 0$ & $2 \cdot 14$ & 2.66 & 1.88 & 1.97 \\
\hline $5 \cdot 0$ & $5 \cdot 0$ & 0.5 & $1 \cdot 0$ & $3 \cdot 0$ & $2 \cdot 76$ & $3 \cdot 18$ & $2 \cdot 44$ & $2 \cdot 39$ \\
\hline $5 \cdot 0$ & $5 \cdot 0$ & $0 \cdot 3$ & 0.5 & $3 \cdot 0$ & $2 \cdot 90$ & 2.58 & $2 \cdot 64$ & $2 \cdot 66$ \\
\hline $5 \cdot 0$ & $5 \cdot 0$ & $0 \cdot 3$ & 0.8 & $3 \cdot 0$ & $2 \cdot 48$ & $2 \cdot 62$ & $2 \cdot 22$ & $2 \cdot 22$ \\
\hline $5 \cdot 0$ & $5 \cdot 0$ & $0 \cdot 3$ & $1 \cdot 0$ & $3 \cdot 0$ & $2 \cdot 14$ & $2 \cdot 66$ & 1.88 & 1.97 \\
\hline $5 \cdot 0$ & $5 \cdot 0$ & $0 \cdot 3$ & $3 \cdot 0$ & $3 \cdot 0$ & $1 \cdot 23$ & 2.78 & 0.95 & 0.96 \\
\hline $5 \cdot 0$ & 5.0 & $0 \cdot 3$ & $5 \cdot 0$ & $3 \cdot 0$ & 0.90 & $2 \cdot 85$ & 0.62 & 0.63 \\
\hline $5 \cdot 0$ & $5 \cdot 0$ & $0 \cdot 3$ & $1 \cdot 0$ & $0 \cdot 8$ & 0.91 & $2 \cdot 66$ & 0.64 & 0.62 \\
\hline $5 \cdot 0$ & $5 \cdot 0$ & $0 \cdot 3$ & $1 \cdot 0$ & $1 \cdot 0$ & 0.96 & $2 \cdot 66$ & 0.69 & 0.68 \\
\hline $5 \cdot 0$ & $5 \cdot 0$ & $0 \cdot 3$ & $1 \cdot 0$ & $3 \cdot 0$ & $2 \cdot 14$ & $2 \cdot 66$ & $1 \cdot 88$ & 1.97 \\
\hline $5 \cdot 0$ & $5 \cdot 0$ & $0 \cdot 3$ & $1 \cdot 0$ & $5 \cdot 0$ & $4 \cdot 21$ & 2.66 & 3.94 & 3.90 \\
\hline $5 \cdot 0$ & $5 \cdot 0$ & $0 \cdot 3$ & $1 \cdot 0$ & $8 \cdot 0$ & $6 \cdot 42$ & $2 \cdot 66$ & $6 \cdot 15$ & $6 \cdot 12$ \\
\hline
\end{tabular}

in the range of 0.05 to $0.50 \mathrm{~mol} \mathrm{dm}^{-3}$ at constant concentrations of L-lysine, DPA, Ru(III) and a constant ionic strength of $0.50 \mathrm{~mol} \mathrm{\textrm {dm } ^ { - 3 }}$. The rate constants increased with increasing [alkali] and the order was found to be less than unity $(0.58)$.

Periodate concentration was varied from $5.0 \times 10^{-5}$ to $5.0 \times 10^{-4}$ at constant [DPA], [L-lys], [OH ${ }^{-}$, $[\mathrm{Ru}(\mathrm{III})]$ and ionic strength. It was observed that the added periodate shows retarding effect on the reaction (table 1).

Initially added products, Ag (I), and 5-aminopentanal did not affect the rate of reaction. It was found that ionic strength and dielectric constant of the medium had no significant effect on the rate of reaction.

The $[\mathrm{Ru}(\mathrm{III})]$ concentrations was varied from $8 \cdot 0 \times 10^{-7}$ to $8 \cdot 0 \times 10^{-6} \mathrm{~mol} \mathrm{dm}^{-3}$ range, at constant concentration of diperiodatoargentate(III), L-lysine, alkali and ionic strength. The order in $[\mathrm{Ru}(\mathrm{III})]$ was found to be unity. The test for free radicals intervention was negative.

The influences of temperature on the rate of reaction were studied at $20,25,30$ and $35^{\circ} \mathrm{C}$. The rate constants, $(k)$, of the slow step of scheme 1 were ob- tained from the slopes and the intercept of the plots of $[\mathrm{Ru}(\mathrm{III})] / k_{C}$ vs $1 /[\mathrm{L}-\mathrm{lys}][\mathrm{Ru}(\mathrm{III})] / k_{C}$ vs $1 /\left[\mathrm{OH}^{-}\right]$ and $[\mathrm{Ru}(\mathrm{III})] / k_{C}$ vs $\left[\mathrm{H}_{3} \mathrm{IO}_{6}^{2-}\right]$ at four different temperatures. The $k \times 10^{-4}\left(\mathrm{dm}^{3} \mathrm{~mol}^{-1} \mathrm{~s}^{-1}\right)$ values are $1 \cdot 82,1 \cdot 97,2 \cdot 07,2 \cdot 15$, at $293,298,303$ and $308 \mathrm{~K}$ respectively. The activation parameters for the rate determining step were obtained as $E_{a}\left(\mathrm{~kJ} \mathrm{~mol}^{-1}\right)=$ $8 \cdot 35 \pm 0.30, \Delta H^{\#}\left(\mathrm{~kJ} \mathrm{~mol}^{-1}\right)=5.87 \pm 0.23, \Delta S^{\#}\left(\mathrm{JK}^{-1}\right.$ $\left.\mathrm{mol}^{-1}\right)=-142 \cdot 7 \pm 6 \cdot 4, \Delta G^{\#}\left(\mathrm{~kJ} \mathrm{~mol}^{-1}\right)=48 \cdot 4 \pm 2 \cdot 0$, $\log A=5 \cdot 76 \pm 0.26$.

\subsection{Catalytic activity}

It has been pointed out by Moelwyn-Hughes ${ }^{13}$ that in presence of the catalyst, the uncatalysed and catalysed reactions proceed simultaneously, so that

$$
k_{T}=k_{U}+K_{C}[\text { catalyst }]^{x}
$$

Therefore

$$
K_{C}=\frac{k_{T}-k_{U}}{[\text { Catalyst }]^{x}}=\frac{k_{C}}{[\text { Catalyst }]^{x}}
$$

where $k_{T}-k_{U}=k_{C}$. 


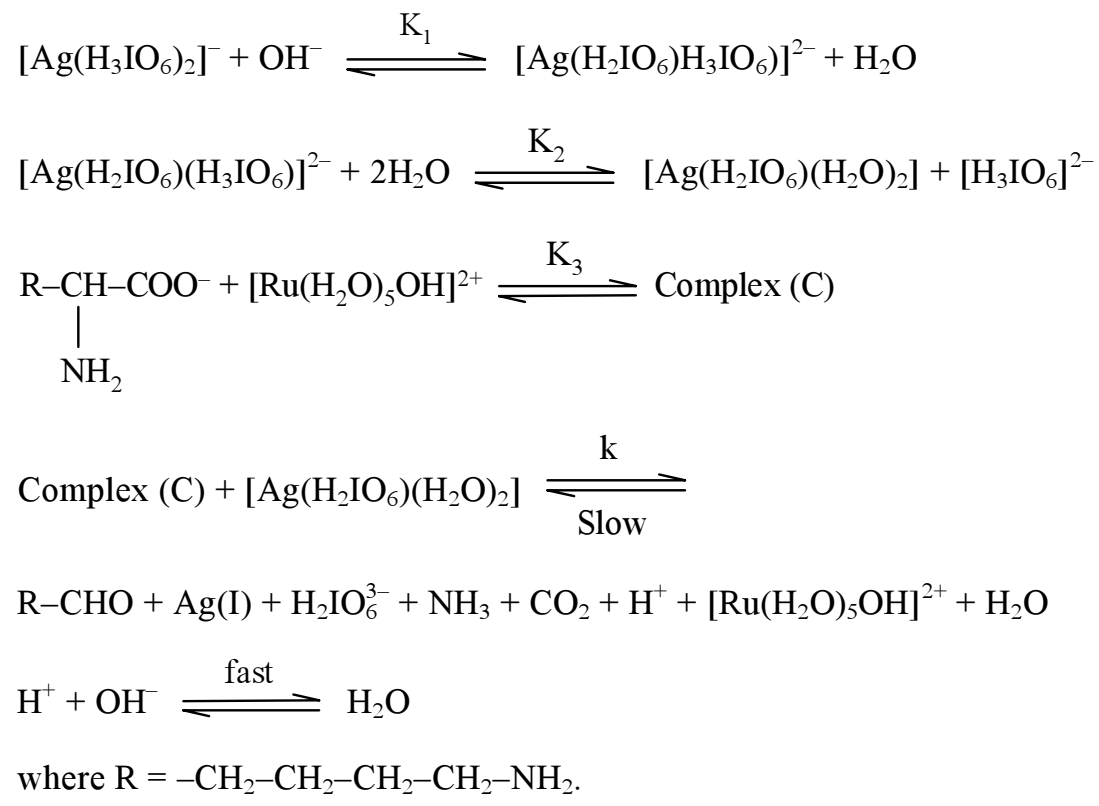

Scheme 1.

Here $K_{C}$ the catalytic constant and $x$ the order of the reaction with respect to $\mathrm{Ru}(\mathrm{III})$. The values of $K_{c} \times 10^{-3}$ are $11 \cdot 6,18 \cdot 8,25 \cdot 1,31 \cdot 6$ at $293,298,303$, $308 \mathrm{~K}$ and energy of activation and other activation parameters with reference to catalyst were computed as $E_{a} \quad\left(\mathrm{~kJ} \mathrm{~mol}^{-1}\right)=49 \cdot 5, \quad \Delta H^{\#} \quad\left(\mathrm{~kJ} \mathrm{~mol}^{-1}\right)=47 \cdot 0$, $\Delta S^{\#}\left(\mathrm{JK}^{-1} \mathrm{~mol}^{-1}\right)=-14, \Delta G^{\#}\left(\mathrm{~kJ} \mathrm{~mol}^{-1}\right)=51, \log A=$ $12 \cdot 5$.

\section{Discussion}

The water soluble diperiodatoargentate(III) (DPA) has a formula $\left[\mathrm{Ag}\left(\mathrm{IO}_{6}\right)_{2}\right]^{7-}$ with $\mathrm{dsp}^{2}$ configuration of square planar structure, similar to diperiodatocopper(III) complex with two bidentate ligands, periodate to form a planar molecule. When the same molecule is used in alkaline medium, it is unlikely to exist as $\left[\mathrm{Ag}\left(\mathrm{IO}_{6}\right)_{2}\right]^{7-}$ as periodate is known to be in various protonated forms ${ }^{14}$ depending on $\mathrm{pH}$ of the solution.

Periodic acid exists as $\mathrm{H}_{5} \mathrm{IO}_{6}$ in acid medium and as $\mathrm{H}_{4} \mathrm{IO}_{6}^{-}$at $\mathrm{pH}$ 7. Thus, under the present alkaline conditions, the main species are expected to be $\mathrm{H}_{3} \mathrm{IO}_{6}^{2-}$ and $\mathrm{H}_{2} \mathrm{IO}_{6}^{3-}$. At higher concentrations, periodate also tends to dimerise. ${ }^{4}$ However, formation of this species is negligible under conditions employed for kinetic study. On the contrary, the authors ${ }^{6}$ in their recent studies have proposed the DPA species as $\left[\mathrm{Ag}(\mathrm{HL})_{2}\right]^{x-}$ in which ' $\mathrm{L}$ ' is a periodate with un- certain number of protons and ' $\mathrm{HL}$ ' is a protonated periodate of uncertain number of protons. This can be ruled out by considering the alternative form ${ }^{14}$ of $\mathrm{IO}_{4}^{-}$at $\mathrm{pH}>7$ which is in the form $\mathrm{H}_{3} \mathrm{IO}_{6}^{2-}$ or $\mathrm{H}_{2} \mathrm{IO}_{6}^{3-}$. Hence, DPA could be as $\left[\mathrm{Ag}\left(\mathrm{H}_{3} \mathrm{IO}_{6}\right)_{2}\right]^{-}$or $\left[\mathrm{Ag}\left(\mathrm{H}_{2} \mathrm{IO}_{6}\right)_{2}\right]^{3-}$ in alkaline medium. Therefore, under the present condition, diperiodatoargentate(III), may be depicted as $\left[\mathrm{Ag}\left(\mathrm{H}_{3} \mathrm{IO}_{6}\right)_{2}\right]^{-}$. The similar speciation of periodate in alkali was proposed ${ }^{15}$ for diperiodatonickelate(IV).

In the present study, it is quite probable that the $\left[\mathrm{Ru}(\mathrm{III})(\mathrm{OH})_{x}\right]^{3-x}$, the $x$ - value would always be less than six because there are no definite reports of any hexahydroxy ruthenium species. The remainder of the coordination sphere would be filled by water molecules. Hence, under the conditions employed, e.g. $\left[\mathrm{OH}^{-}\right]>>[\mathrm{Ru}(\mathrm{III})]$, ruthenium(III) is mostly present $^{16}$ as the hydroxylated species, $\left[\mathrm{Ru}\left(\mathrm{H}_{2} \mathrm{O}\right)_{5}\right.$ $\mathrm{OH}]^{2+}$. It is known that L-lysine exists in the form of Zwitterion ${ }^{17}$ in aqueous medium. In highly acidic medium, it exists in the protonated form, where as in highly basic medium it is in the fully deprotonated form. ${ }^{17}$

Since, the reaction was enhanced by $\left[\mathrm{OH}^{-}\right]$, added periodate retarded the rate and there was first order dependency in [DPA] and catalyst [Ru(III)] and fractional order in [L-lysine] and $\left[\mathrm{OH}^{-}\right]$, scheme 1 has been proposed which explains all other experimental observation. 

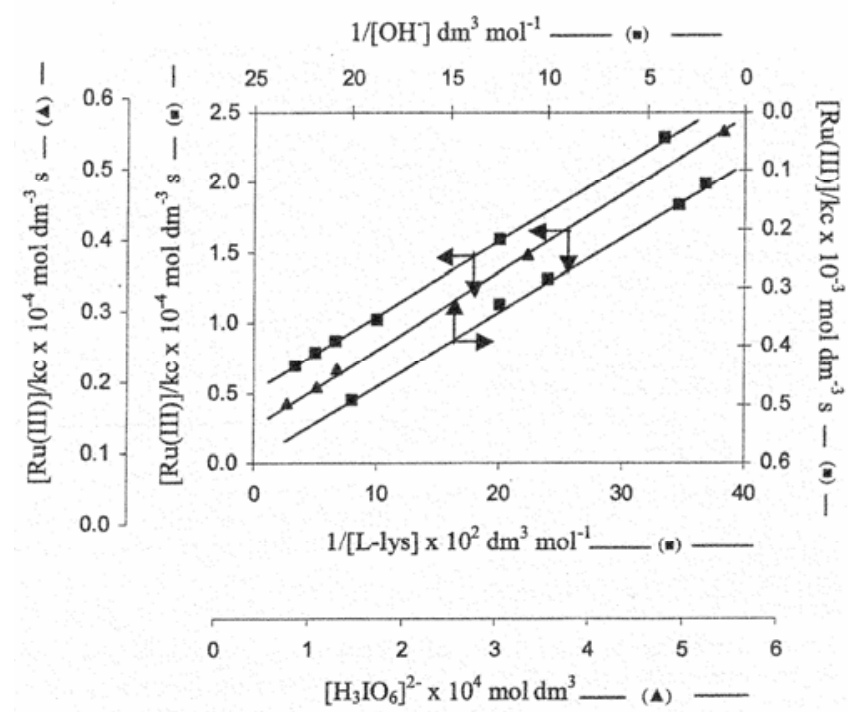

Figure 1. Verification of rate law (4) of $\mathrm{Ru}(\mathrm{III})$ catalysed oxidation of L-lysine by diperiodatoargentate(III) at $25^{\circ} \mathrm{C}$.

In the prior equilibrium step 1 , the $\left[\mathrm{OH}^{-}\right]$deprotonates the DPA to give a deprotonated diperiodatoargentate(III). In the second step, displacement of a ligand, periodate takes place to give free periodate which is evidenced by decrease in the rate with increase in [periodate] (table 1). It may be expected that lower $\operatorname{Ag}(\mathrm{III})$ periodate species such as monoperiodatoargentate(III)(MPA) is more important active species in the reaction than the DPA. The inverse fractional order in $\left[\mathrm{H}_{3} \mathrm{IO}_{6}\right]^{2-}$ might also be due to this reason. In the pre rate determining stage, the $\mathrm{Ru}(\mathrm{III})$ species combines with a molecule of anionic species of L-lysine to give an intermediate complex (C), which further reacts with one mole of monoperiodatoargentate(III)(MPA) in a rate determining step to give the products as given in scheme 1 .

Spectroscopic evidence for the complex (C) formation between catalyst and substrate was obtained from UV-Vis spectra of L-lysine $\left(5 \cdot 0 \times 10^{-4}\right), \mathrm{Ru}(\mathrm{III})$ $\left(3.0 \times 10^{-6}\right),\left[\mathrm{OH}^{-}\right]\left(0.30 \mathrm{~mol} \mathrm{dm}^{-3}\right)$ and the mixture of both. A hypsochromic shift of about $4 \mathrm{~nm}$ from $756 \mathrm{~nm}$ to 752 in the spectra of mixture of L-lysine and $\mathrm{Ru}(\mathrm{III})$ was observed. The Michelis-Menten plot proved (i.e. kinetic evidence $1 / k_{c}$ vs $1 /$ [L-lys] (figure 1)) the complex formation between catalyst and reductant, which explains less than unit order in [Llys]. Such a complex between a substrate and a catalyst has been observed in other studies. ${ }^{18}$ The rate law (3) for the scheme 1 could be derived as, (for detailed derivation, see appendix I).

$$
\begin{aligned}
\frac{\text { Rate }}{[\mathrm{DPA}]}=k_{C}=k_{T}-k_{U} \\
=\frac{k K_{1} K_{2} K_{3}[\mathrm{~L}-l y \operatorname{sine}]\left[\mathrm{OH}^{-}\right][\mathrm{Ru}(\mathrm{III})]}{\left[\mathrm{H}_{3} \mathrm{IO}_{6}^{2-}\right]+K_{1}\left[\mathrm{OH}^{-}\right]\left[\mathrm{H}_{3} \mathrm{IO}_{6}^{2-}\right]+} \\
K_{1} K_{2}\left[\mathrm{OH}^{-}\right]+K_{1} K_{2} K_{3}\left[\mathrm{OH}^{-}\right][\mathrm{L}-l y s i n e]
\end{aligned}
$$

Equation (3) can be rearranged into (4), which is suitable for verification

$$
\begin{aligned}
\frac{[\mathrm{Ru}(\mathrm{III})]}{k_{c}} & =\frac{\left[\mathrm{H}_{3} \mathrm{IO}_{6}^{2-}\right]}{k K_{1} K_{2} K_{3}[\mathrm{~L}-\text { lysine }]\left[\mathrm{OH}^{-}\right]} \\
& +\frac{\left[\mathrm{H}_{3} \mathrm{IO}_{6}^{2-}\right]}{k K_{2} K_{3}[\mathrm{~L}-\text { lysine }]}+\frac{1}{k K_{3}[\mathrm{~L}-\text { lysine }]}+\frac{1}{k} .
\end{aligned}
$$

According to (4), plots of $[\mathrm{Ru}(\mathrm{III})] / k_{c}$ vs $\left[\mathrm{H}_{3} \mathrm{IO}_{6}^{2-}\right]$, $[\mathrm{Ru}(\mathrm{III})] / k_{c}$ vs $1 /\left[\mathrm{OH}^{-}\right]$and $[\mathrm{Ru}(\mathrm{III})] / k_{c}$ vs $1 /[\mathrm{L}-$ lysine] were linear (figure 1). From the intercepts and slopes of such plots, the reaction constants $K_{1}$, $K_{2}, K_{3}$ and $k$ were calculated as $(0.60 \pm 0.03) \mathrm{dm}^{3}$ $\mathrm{mol}^{-1}, \quad(1.83 \pm 0.06) \times 10^{-4} \mathrm{~mol} \mathrm{dm}^{-3}, \quad(4.56 \pm 0.12) \times$ $10^{3} \mathrm{dm}^{3} \mathrm{~mol}^{-1},(1.97 \pm 0.03) \times 10^{4} \mathrm{dm}^{3} \mathrm{~mol}^{-1} \mathrm{~s}^{-1}$ respectively. These constants were used to calculate the rate constants and compared with the experimental $k_{c}$ values and found to be in reasonable agreement with each other (table 1), which fortifies the scheme 1 . The equilibrium constant $K_{1}$ is far greater than $K_{2}$, which may be attributed to the greater tendency of DPA to undergo deprotonation compared to the formation of hydrolysed species in alkaline medium.

Negligible effect of ionic strength and dielectric constant might be due to involvement of neutral substrate in the reaction (scheme 1). The moderate $\Delta H^{\#}$ and $\Delta S^{\#}$ values are favourable for electron transfer reaction. The value of $\Delta H^{\#}$ was due to energy of solution changes in the transition state. The negative value of $\Delta S^{\#}$ suggests that the intermediate complex is more ordered than the reactants. ${ }^{19}$ The observed modest enthalpy of activation and a higher rate constant for the slow step indicates that the oxidation presumably occurs via an inner-sphere mechanism. This conclusion is supported by earlier observations. ${ }^{20}$ The activation parameters evaluated for the catalysed and uncatalysed reaction explain the catalytic effect on the reaction. The catalyst $\mathrm{Ru}(\mathrm{III})$ form the complex (C) with substrate which enhances the reducing property of the substrate than that with out catalyst. Further, the catalyst Ru(III) modifies 
the reaction path by lowering the energy of activation. we have calculated the isokinetic temperature $(\beta)$ as $588 \mathrm{~K}$ by plotting $\log k_{2}$ at $303 \mathrm{~K}$ versus $\log k_{1}$ at $298 \mathrm{~K}$ as per Exner. ${ }^{21}$ The value of $\beta(588 \mathrm{~K})$ is higher than experimental temperature $(298 \mathrm{~K})$. This indicates that the rate is governed by the enthalpy of activation. ${ }^{22}$ The linearity and the slope of the plot obtained may confirm that the kinetics of these reactions follow similar mechanism, as previously suggested.

\section{Appendix I}

According to scheme 1

$$
\begin{aligned}
\text { Rate }= & k[\mathrm{C}]\left[\mathrm{Ag}\left(\mathrm{H}_{2} \mathrm{IO}_{6}\right)\left(\mathrm{H}_{2} \mathrm{O}\right)_{2}\right] \\
& =\frac{\left[\mathrm{Ru}\left(\mathrm{H}_{2} \mathrm{O}\right)_{5} \mathrm{OH}\right]^{2+}[\mathrm{L}-\text { lysine }][\mathrm{OH}]^{-}}{\left[\mathrm{H}_{3} \mathrm{IO}_{6}\right]^{2-}}
\end{aligned}
$$

The total DPA concentration is given in

$$
\begin{aligned}
{[\mathrm{DPA}]_{\mathrm{T}}=[\mathrm{DPA}]_{\mathrm{f}}+\left[\mathrm{Ag}\left(\mathrm{H}_{2} \mathrm{IO}_{6}\right)\left(\mathrm{H}_{3} \mathrm{IO}_{6}\right)\right]^{2-} } \\
+\left[\mathrm{Ag}\left(\mathrm{H}_{2} \mathrm{IO}_{6}\right)\left(\mathrm{H}_{2} \mathrm{O}\right)_{2}\right]
\end{aligned}
$$

where $\mathrm{T}$ and $\mathrm{f}$ refer to total and free concentrations.

$$
\begin{aligned}
& {[\mathrm{DPA}]_{\mathrm{f}}=} \\
& \frac{[\mathrm{DPA}]_{\mathrm{T}}\left[\mathrm{H}_{3} \mathrm{IO}_{6}^{2-}\right]}{\left[\mathrm{H}_{3} \mathrm{IO}_{6}^{2-}\right]+K_{1}\left[\mathrm{OH}^{-}\right]\left[\mathrm{H}_{3} \mathrm{IO}_{6}^{2-}\right]+K_{1} K_{2}\left[\mathrm{OH}^{-}\right]} \\
& {\left[\mathrm{OH}^{-}\right]_{\mathrm{T}}=\left[\mathrm{OH}^{-}\right]_{\mathrm{f}}+\left[\mathrm{Ag}\left(\mathrm{H}_{2} \mathrm{IO}_{6}\right)\left(\mathrm{H}_{3} \mathrm{IO}_{6}\right)\right]^{2-}} \\
& +\left[\mathrm{Ag}\left(\mathrm{H}_{2} \mathrm{IO}_{6}\right)\left(\mathrm{H}_{2} \mathrm{O}\right)_{2}\right] \\
& =\left[\mathrm{OH}^{-}\right]_{\mathrm{f}}+K_{1}\left[\mathrm{OH}^{-}\right][\mathrm{DPA}]+\frac{K_{1} K_{2}[\mathrm{DPA}]\left[\mathrm{OH}^{-}\right]}{\left[\mathrm{H}_{3} \mathrm{IO}_{6}^{2-}\right]}
\end{aligned}
$$

In view of the low concentration of [DPA] and $\left[\mathrm{H}_{3} \mathrm{IO}_{6}^{2-}\right]$ used,

$$
[\mathrm{OH})_{\mathrm{T}}=[\mathrm{OH}]_{\mathrm{f}}
$$

$[\mathrm{L}-\mathrm{lys}]_{\mathrm{T}}=[\mathrm{L}-\mathrm{lys}]_{\mathrm{f}}+[\mathrm{C}]=[\mathrm{L}-\mathrm{lys}]_{\mathrm{f}}\left[1+K_{3}[(\mathrm{Ru}(\mathrm{III})]]\right.$.
In view of the low concentration of $[\mathrm{Ru}(\mathrm{III})]$ used,

$$
\begin{aligned}
& {[\mathrm{L}-\mathrm{lys}]_{\mathrm{T}}=[\mathrm{L}-\mathrm{lys}]_{\mathrm{f}}} \\
& \begin{array}{l}
{[\mathrm{Ru}(\mathrm{III})]_{\mathrm{T}}=[\mathrm{Ru}(\mathrm{III})]_{\mathrm{f}}+[\mathrm{C}]=[\mathrm{Ru}(\mathrm{III})]_{\mathrm{f}}} \\
+\left[1+K_{3}[\mathrm{~L}-\mathrm{lys}]\right]
\end{array} \\
& {[\mathrm{Ru}(\mathrm{III})]_{\mathrm{f}}=\frac{[\mathrm{Ru}(\mathrm{III})]_{\mathrm{T}}}{1+K_{3}[\mathrm{~L}-\mathrm{lys}]}}
\end{aligned}
$$

Substituting (II), (III), (IV) and (V) in (I) and omitting the subscripts $\mathrm{T}$ and $\mathrm{f}$ we get

$$
\begin{aligned}
\frac{\text { Rate }}{[\mathrm{DPA}]}= & k_{C}=k_{T}-k_{U} \\
= & \frac{k K_{1} K_{2} K_{3}[\mathrm{~L}-\text { lysine }]\left[\mathrm{OH}^{-}\right][\mathrm{Ru}(\mathrm{III})]}{\left[\mathrm{H}_{3} \mathrm{IO}_{6}^{2-}\right]+K_{1}\left[\mathrm{OH}^{-}\right]\left[\mathrm{H}_{3} \mathrm{IO}_{6}^{2-}\right]} \\
& +K_{1} K_{2}\left[\mathrm{OH}^{-}\right]+K_{1} K_{2} K_{3}\left[\mathrm{OH}^{-}\right][\mathrm{L}-\text { lysine }]
\end{aligned}
$$

\section{References}

1. Lalo D and Mahanti M K 1990 J. Chem. Soc. Dalton Trans. 311

2. Bal Reddy K, Sethuram B and Navaneeth Rao T 1981 Indian. J. Chem. A20 395

3. Flodin N W 1997 J. Am. Coll Nutr. 167

4. Sethuram B 2003 Some aspects of electron transfer reactions involving organic molecules (New Delhi: Allied Publishers (P) Ltd) pp 78, 151

5. (a) Jaiswal P K and Yadav K L 1970 Talanta 17 236; (b) Jaiswal P K 1972 Analyst 1503

6. (a) Jayaprakash Rao P, Sethuram B and Navaneeth Rao T 1985 React. Kinet. Catal. Lett. 29 289; (b) Venkata Krishna K and Jayaprakash Rao P 1998 Indian J. Chem. A37 1106 references therein

7. (a) Kumar A and Kumar P 1999 J. Phys. Org. Chem. 12 79; (b) Kumar A, Vaishali P and Ramamurthy 2000 Int. J. Chem. Kinet. 32286

8. Munavalli D S, Chimatadar S A and Nandibewoor S T 2008 Transition. Met. Chem. 33535

9. Reddy C S and Vijaykumar T 1995 Indian J. Chem. A34 615

10. Panigrahi G P and Misro P K 1977 Indian J. Chem. A15 1066

11. Cohen G L and Atkinson G 1964 Inorg. Chem. 3 1741

12. Jeffery G H, Bassett J, Mendham J and Denney R C 1996 Vogel's textbook of quantitative chemical analysis 5th edn (Singapore: Longmans Singapore Publishers Pte Ltd.) pp. 391 and 467

13. Moelwyn-Hughes E A 1947 Kinetics of reaction in solutions (London: Oxford University Press) 
14. (a) Crouthumel C E, Meek H V, Martin D S and Banus C V $1949 \mathrm{~J}$. Am. Chem. Soc. 71 3031; (b) Crouthamel C E, Hayes A M and Martin D S $1951 J$. Am. Chem. Soc. 7382

15. (a) Bhattacharya S, Saha B, Datta A and Banerjee $P$ 1988 Coord. Chem. Rev. 47 170; (b) Haines R I and McAuley A 1981 Coord. Chem. Rev. 3977

16. Desai S M, Halligudi N N and Nandibewoor S T 2002 Transition Met. Chem. 27207

17. Chang R 1981 Physical chemistry with applications to biological systems (New York: McMillan) p. 326
18. Seregar V C, Veeresh $\mathrm{T} \mathrm{M}$ and Nandibewoor $\mathrm{S} T$ 2007 Polyhedron 261731

19. Weissberger A and Lewis E S (eds) 1974 Investigation of rates and mechanism of reactions in techniques of chemistry (New York: Wiley) 4421

20. Farokhi S A and Nandibewoor S T 2003 Tetrahedron 597595

21. (a) Exner O 1964 Coll. Czech. Chem. Commun. 29 1094; (b) Exner O 1972 Coll. Czech. Chem. Commun. 371425

22. Leffler J E 1955 J. Org. Chem. 201202 